\title{
Epstein-Barr Virus Infection and Increased Sporadic Breast Carcinoma Risk: A Meta-Analysis
}

\author{
Qing'e Jin Jianrong Su Donghui Yan Shanna Wu
}

Department of Clinical Laboratory, The Second Clinical Medical College of Capital Medical University, Beijing Friendship Hospital, Beijing, China

\section{Significance of the Study}

- We evaluated the relationship between Epstein-Barr virus (EBV) infection and breast carcinoma (BC) risk in 16 studies with 1,279 patients and 814 controls and found that EBV infection was significantly associated with BC risk.

- The findings may contribute to furthering our understanding of the role of EBV in the pathogenesis of $\mathrm{BC}$ and optimize therapeutic strategies for the treatment of BC.

\section{Keywords}

Epstein-Barr virus · Breast cancer · Meta-analyses

\section{Abstract}

Objective: An association of Epstein-Barr virus (EBV) infection with breast carcinoma $(B C)$ risk has so far been disputed in the literature. Therefore, we performed a meta-analysis to clarify this relationship. Materials and Methods: An electronic database search for eligible case-control studies was performed using PubMed, Embase, Web of Science, the Cochrane Library, CNKI, and Wanfang Data until May 17, 2018. The pooled OR and $95 \% \mathrm{Cl}$ were used to estimate the relationship between $E B V$ infection and $B C$ risk using a fixed or random-effects model depending on heterogeneity. Subgroup analysis and meta-regression were used to explore the heterogeneity. Publication bias was assessed using Egger's and Harbord's tests. Results: A total of 16 studies with 1,279 patients and 814 controls were reviewed based on our inclusion and exclusion criteria. Compared with the control

\begin{tabular}{ll}
\hline KARGER & $\begin{array}{l}\text { (c) } 2019 \text { The Author(s) } \\
\text { Published by S. Karger AG, Basel }\end{array}$ \\
karger@karger.com & This is an Open Access article licensed under the Creative Commons \\
www.karger.com/mpp & $\begin{array}{l}\text { Attribution-NonCommercial-4.0 International License (CC BY-NC) } \\
\text { (http://www.karger.com/Services/OpenAccessLicense), applicable to } \\
\text { the online version of the article only. Usage and distribution for com- } \\
\text { mercial purposes requires written permission. }\end{array}$
\end{tabular}

group, EBV infection had a significant association with $B C$ risk (OR 4.75, 95\% Cl 2.53-8.92, $p<0.01$ ) with significant heterogeneity observed $\left(R^{2}=65.3 \%\right)$. The subgroup analysis revealed that region and tissue type might explain potential sources of heterogeneity. The sensitivity analyses yielded stable results. No significant publication bias was observed. Conclusion: The current results suggest that EBV infection is significantly associated with increased risk of BC.

(c) 2019 The Author(s)
Published by S. Karger AG, Basel

\section{Introduction}

Breast carcinoma (BC) is the most common malignancy that affects women worldwide [1]. The high disease burden highlights the need to better understand its etiology, but conventional risk factors such as genetic variation, hormones, and environmental factors only account for approximately $50 \%$ of the causes. A possible viral etiology from Epstein-Barr virus (EBV), mouse mammary 
tumor virus (MMTV), bovine leukemia virus, and human papillomavirus (HPV) has been proposed. EBV is an oncogenic human herpesvirus persisting with lifelong latent infection in the majority of infected people [2]. The virus has been well known as a causative agent for several types of tumor, such as nasopharyngeal carcinoma, lymphomas, and oral squamous cell carcinoma [3].

Since 1995, the association of EBV infection with BC risk has been studied [4]. However, controversial results were reported. Several mechanisms for oncogenic EBV and $\mathrm{BC}$ risk have been investigated, indicating a potentially important role for EBV infection in BC pathogenesis. Thus, a meta-analysis was performed to evaluate the relationship.

\section{Materials and Methods}

\section{Search Strategy}

Our meta-analysis was performed in compliance with the Meta-Analysis of Observational Studies in Epidemiology (MOOSE) statement guidelines [5]. A computerized literature search on PubMed, Embase, Web of Science, and the Cochrane Library for English-language publications, as well as on CNKI and Wanfang Data for Chinese-language publications, was conducted until May 17, 2018. The MeSH words used were the following keywords: (((("Epstein-Barr virus" [Title/Abstract]) or "EBV" [Title/Abstract]) or "human herpesvirus 4" [Title/Abstract]) or "HHV4" [Title/Abstract]) and ((" "breast neoplasms" [Title/Abstract]) or "breast carcinoma" [Title/Abstract]) or "breast cancer" [Title/Abstract]). The titles and abstracts of the articles were carefully checked independently by two authors (Q.J. and S.W.) to determine if the full texts should be obtained.

\section{Inclusion and Exclusion Criteria}

The extracted data were required to meet the following criteria: (1) designed as a case-control study; (2) confirmed BC by histopathological diagnosis; (3) evaluated EBV infection by detecting the expression level (DNA, RNA, or protein) in tissue samples; (4) use of PCR, quantitative PCR, in situ hybridization (ISH), and immunohistochemistry (IHC); (5) only sporadic, not familial BC; and (6) full text available.

Studies meeting more than one of the following criteria were excluded: (1) animal research, in vitro study, case report, review, editorial, or commentary; (2) the available data could not be extracted by calculation from the article or by contacting the authors; and (3) duplicate publication.

\section{Data Extraction}

The data were extracted independently by two authors (Q.J. and S.W.) using a predesigned form. Discrepancies were discussed and resolved within the research team. The following information was recorded: first author; publication year; journal name; country of origin (Asia, Africa, Europe, North America, South America, and Oceania); numbers of cases and controls; detection method and marker; sample type (paraffin-embedded tissue or fresh/frozen tissue); and control type.
Quality Assessment

The quality of the papers was assessed independently by two authors (Q.J. and S.W.) according to the Newcastle-Ottawa Scale (NOS) [6], where a score of $\geq 6$ indicates moderate-to-high quality.

\section{Statistical Analysis}

The statistical analysis was carried out using Stata software (version 14.1). Forest plots were generated to evaluate the pooled effects. Heterogeneity was assessed using Cochran's Q test and the $I^{2}$ statistic with a significance level of $p<0.10$ or $I^{2}>50 \%$. Depending on the heterogeneity test results, a fixed-effects or a randomeffects model was adopted for the next analyses. Subgroup analysis and meta-regression were conducted when heterogeneity was evident based on vital variables (study location, tissue type, and publication year). A sensitivity analysis was performed to estimate the influence of a single study on the pooled ORs. Egger's test and Harbord's weighted linear regression test were used to assess publication bias. All $p$ values were two-sided, and the significance level was 0.05 .

\section{Results}

\section{Study Selection}

A total of 609 articles were selected from the databases. 560 citations were excluded due to duplication, irrelevant literature, being a review, or including no controls, and the remaining 49 articles were screened using the full text. Sixteen studies comprising 1,279 cases and 814 controls were finally included in the meta-analysis according to the eligibility criteria (online suppl. Fig. S1; see www. karger.com/doi/10.1159/000502131 for all online suppl. material).

\section{Study Characteristics and Quality Assessment}

The 16 included studies were published between 1995 and 2018 [7-22]. The prevalence of EBV infection ranged from $0 \%$ [17] to $60.0 \%$ [13] and the overall EBV positivity was $28.5 \%$. The number of included BC patients ranged from 40 [20] to 144 [9] per study. The EBV prevalence was highest among Asian subjects and lowest among North American subjects. There was no significant difference in EBV infection by year of publication. The characteristics of the included articles are summarized, and the quality of the papers scored, in Table 1 . The NOS scores ranged from 6 to 8 , indicating a relatively high quality.

\section{Statistical Pooling between EBV Infection and \\ Risk of $B C$}

The pooled ORs showed that EBV infection had an association with increased BC risk (OR 4.75, 95\% CI 2.53$8.92, p<0.01)$ in the random-effects model due to sig- 
Table 1. Detailed information and quality assessment of included studies in the meta-analysis

\begin{tabular}{|c|c|c|c|c|c|c|c|c|c|c|c|}
\hline First author [Ref.] & Year & $\begin{array}{l}\text { Study } \\
\text { location }\end{array}$ & + & - & + & - & $\begin{array}{l}\text { Detection } \\
\text { method }\end{array}$ & $\begin{array}{l}\text { Detection } \\
\text { marker }\end{array}$ & $\begin{array}{l}\text { Tissue } \\
\text { type }\end{array}$ & $\begin{array}{l}\text { Control } \\
\text { type }\end{array}$ & $\begin{array}{l}\text { NOS } \\
\text { score }\end{array}$ \\
\hline Pai [7] & 2018 & India & 25 & 58 & 0 & 7 & ISH & EBERs & $\mathrm{PE}$ & $\begin{array}{l}\text { Benign breast } \\
\text { diseases }\end{array}$ & 7 \\
\hline EI-Naby [8] & 2017 & Egypt & 10 & 32 & 6 & 36 & $\begin{array}{l}\text { Nested PCR, } \\
\text { IHC }\end{array}$ & EBNA-1, LMP-1 & PE & $\begin{array}{l}\text { Benign breast } \\
\text { diseases }\end{array}$ & 7 \\
\hline Richardson [10] & 2015 & $\begin{array}{l}\text { New } \\
\text { Zealand }\end{array}$ & 24 & 46 & 9 & 61 & qPCR & EBNA-1 & Fresh/FT & $\begin{array}{l}\text { Normal breast } \\
\text { tissues }\end{array}$ & 7 \\
\hline Yahia [11] & 2014 & Sudan & 49 & 43 & 12 & 38 & PCR, ISH & LMP-1, EBERs & Fresh/FT & $\begin{array}{l}\text { Normal breast } \\
\text { tissues }\end{array}$ & 7 \\
\hline Peng [13] & 2014 & China & 60 & 40 & 16 & 34 & PCR-MS, ISH & EBERs & Fresh/FT & $\begin{array}{l}\text { Benign breast } \\
\text { diseases }\end{array}$ & 8 \\
\hline Khabaz [14] & 2013 & Jordan & 24 & 68 & 3 & 46 & PCR, IHC & EBER-2, EBNA-1 & $\mathrm{PE}$ & $\begin{array}{l}\text { Benign breast } \\
\text { diseases }\end{array}$ & 7 \\
\hline Zekri [16] & 2012 & Iraq & 14 & 36 & 0 & 20 & PCR, IHC, ISH & $\begin{array}{l}\text { EBNA-1, LMP-1, } \\
\text { EBERs }\end{array}$ & PE & $\begin{array}{l}\text { Normal breast } \\
\text { tissues }\end{array}$ & 6 \\
\hline Hachana [18] & 2011 & Tunisia & 33 & 90 & 0 & 123 & PCR & EBV DNA & Fresh/FT & $\begin{array}{l}\text { Normal breast } \\
\text { tissues }\end{array}$ & 8 \\
\hline Kadivar [17] & 2011 & Iran & 0 & 100 & 0 & 42 & PCR, IHC & $\begin{array}{l}\text { EBERs, EBNA-2, } \\
\text { LMP }\end{array}$ & PE & $\begin{array}{l}\text { Benign breast } \\
\text { diseases }\end{array}$ & 6 \\
\hline Joshi [19] & 2009 & India & 28 & 23 & 0 & 30 & $\mathrm{IHC}$ & EBNA-1 & $\mathrm{PE}$ & $\begin{array}{l}\text { Benign breast } \\
\text { diseases }\end{array}$ & 7 \\
\hline Fawzy [20] & 2008 & Egypt & 10 & 30 & 0 & 20 & PCR, IHC & EBNA-1 & $\mathrm{PE}$ & $\begin{array}{l}\text { Benign breast } \\
\text { diseases }\end{array}$ & 7 \\
\hline Kalkan [22] & 2005 & Turkey & 13 & 44 & 19 & 36 & PCR & EBV DNA & $\mathrm{PE}$ & $\begin{array}{l}\text { Benign breast } \\
\text { diseases }\end{array}$ & 6 \\
\hline
\end{tabular}

EBV, Epstein-Barr virus; ISH, in situ hybridization; IHC, immunohistochemistry; EBER, EBV-encoded small nonpolyadenylated RNA; EBNA, EBVdetermined nuclear antigen; LMP, latent membrane protein; PE, paraffin-embedded tissue; NOS, Newcastle-Ottawa Scale; FT, frozen tissue.

nificant heterogeneity between studies $\left(I^{2}=65.3 \%\right)$. One of the studies [17] was excluded after data analysis due to the absence of EBV in both groups. A forest plot of the effect sizes and 95\% CIs is shown in Figure 1.

\section{Heterogeneity, Subgroup Analysis, Meta-Regression,} and Sensitivity Analyses

To explore the heterogeneity between studies, subgroup analysis and meta-regression were performed. Region (Asia/Africa and Europe/America) and tissue type (paraffin-embedded and fresh/frozen tissues) were chosen as variables by group. The results revealed that study location and tissue type could partly account for the heterogeneity. The pooled ORs (95\% CIs) for the respective regions were 4.98 (2.82-8.77) and 3.57 (0.64-19.99), and those for the respective tissue types were $5.62(2.03-15.54)$ and 4.16 (2.17-7.97; online suppl. Fig. S2). The meta-regression analysis revealed that the publication date did not influence heterogeneity $(p=0.760)$. The sensitivity analyses revealed that no single study significantly changed the recalculated pooled ORs (online suppl. Fig. S3).

\section{Publication Bias}

A funnel plot revealed a relatively symmetrical distribution (online suppl. Fig. S4). No publication bias was observed by Egger's test $(p=0.111)$ or Harbord's test $(p=0.468)$ (Fig. 2). 


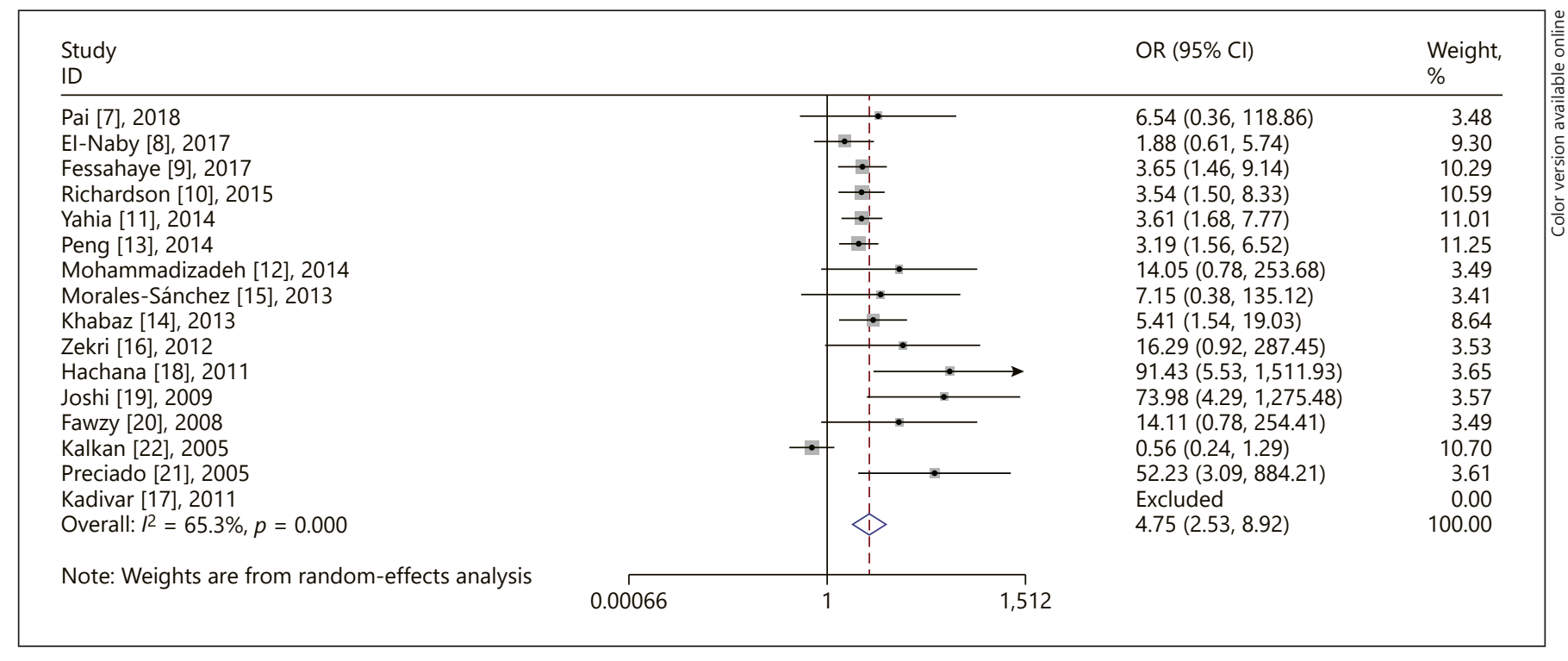

Fig. 1. Forest plot of the association between Epstein-Barr virus (EBV) infection and increased breast carcinoma (BC) risk. Sixteen studies were selected for the meta-analysis. One was excluded automatically after the data analysis due to the absence of EBV in both groups. The random-effects model was chosen for the heterogeneity. A 4.75-fold (95\% CI 2.53-8.92) increased BC risk with EBV infection was shown.

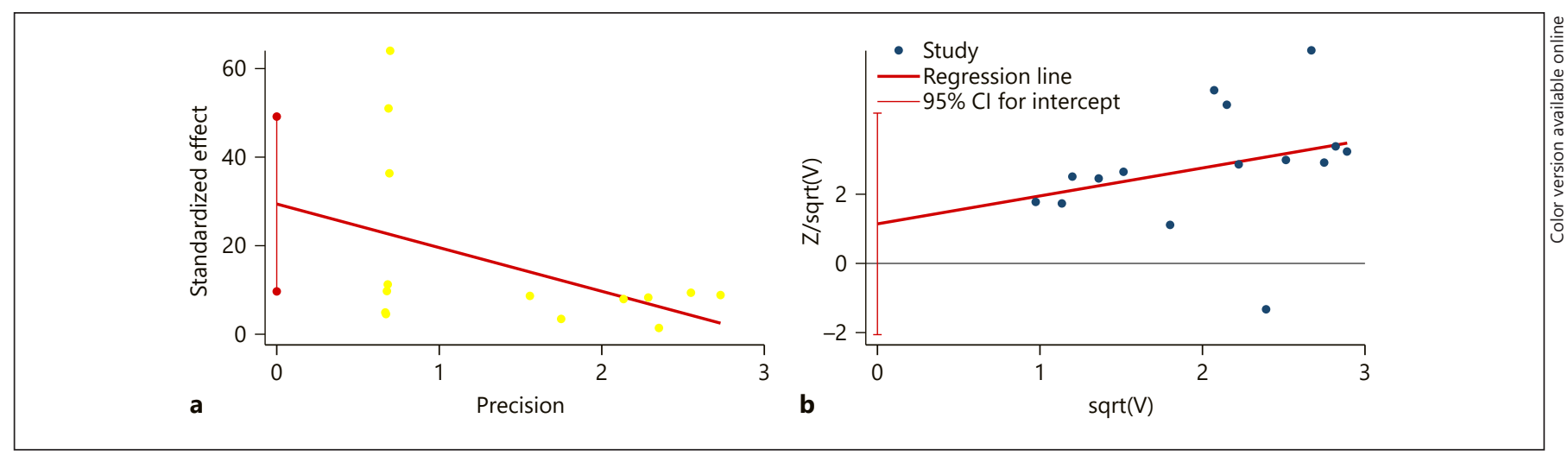

Fig. 2. Estimation of publication bias by Egger's test (a) and Harbord's weighted linear regression test (b). The two kinds of method showed no significant publication bias ( $p=0.111$ and $p=0.468$, respectively).

\section{Discussion}

Based on all the outcomes and our analysis, EBV infection had a significant association with increased BC risk. The high incidence of $\mathrm{BC}$ worldwide has aroused interest in a possible viral etiology. EBV infected more than $90 \%$ of the population worldwide. In 1995, Labrecque et al. [4] detected EBV in epithelial cells of BC. Since then, EBV infection has been investigated as an etiological agent of $\mathrm{BC}$, and the results have been controversial $[4,23]$. The inconsistency could be attributed to several aspects: a study design that involved a specific histological type of $\mathrm{BC}$, differences in methodologies or techniques (PCR, ISH, and IHC), dissimilarities in the archival materials (paraffin-embedded and fresh/frozen tissues), and ethnic origin [24].

Arbach et al. [25] found that EBV genomes were heterogeneously distributed in morphologically identical tumor cells. Another study revealed that EBV was localized to infiltrated lymphocytes rather than malignant breast cells [26]. Therefore, to depend solely on PCR-based approaches to determine the relationship between EBV in- 
fection and BC risk is inappropriate. Indeed, several different techniques should be performed in a single experiment to verify each other's results. Huo et al. [27] performed a pooled analysis of 10 studies on EBV infection and BC risk published during 1995-2008. They found a significant increase in breast malignancy risk among patients with EBV infection (OR 6.29, 95\% CI 2.13-18.59), with a high heterogeneity of $75.9 \%$. Their research used only the PCR technique to detect EBV infection. Since 2012, we have reviewed few reports on the relationship between EBV infection and BC risk.

Our results are consistent with those of Huo's study. In our meta-analysis, 11 of the 16 included studies utilized ISH or IHC or both. Thirteen of the 16 studies, published between 2009 and 2018, represent the latest research progress. Only 3 papers were published during 2005-2008, which were also included in the study by Huo et al. [27]. Moreover, our study had a larger case number, making it more convincing. Heterogeneity is a common problem in meta-analyses, since it could weaken the reliability of the results. The results of our subgroup analysis indicate that geographic region and tissue type could partially account for the heterogeneity observed; otherwise, in the metaregression analysis, the publication date had no influence on the heterogeneity. No publication bias was observed, and the sensitivity analyses also showed stable results.

It is known that oncovirus coinfection could play an important role in human oncogenesis. Research on Pakistani BC patients found that coinfection with EBV and high-risk HPVs suggested a possible synergistic carcinogenic effect [28]. An MMTV-like virus has been a major suspect as a causative virus for BC over 50 years. EBV, $\mathrm{HPV}$, and MMTV gene sequences are present and coexist in $\mathrm{BC}$ patients [29]. Thus, oncovirus coinfection of BC patients also was an important issue to explore. In the future, more attention should be paid to the interaction of oncoviruses during the occurrence of $\mathrm{BC}$.

Although we evaluated the association between EBV infection and BC risk with reliable statistical results, several limitations of the current study should be addressed. The results could be attributable to technical challenges and methods, the study design used with different histological types, and ethnicity, as the majority of the populations studied were Asian and African.

Additional high-quality research with a wider reach and larger sample sizes is required to further confirm the relationship. Treatment for $\mathrm{BC}$ still does not take into account the status of infection with EBV and related viruses in most areas of China. Promising therapeutic approaches based on EBV status should be further explored.

\section{Conclusion}

Based on the current meta-analysis, we suggest that EBV infection is statistically significantly associated with increased BC risk. The findings will help in understanding the role of $\mathrm{EBV}$ in the pathogenesis of $\mathrm{BC}$ and in optimizing therapeutic strategies for BC.

\section{Statement of Ethics}

The authors have no ethical conflicts to disclose.

\section{Disclosure Statement}

The authors declare no conflicts of interest.

\section{References}

1 Oeffinger KC, Fontham ET, Etzioni R, Herzig A, Michaelson JS, Shih YC, et al.; American Cancer Society. Breast cancer screening for women at average risk: 2015 Guideline Update from the American Cancer Society. JAMA. 2015 Oct;314(15):1599-614.

2 Mazouni C, Fina F, Romain S, Ouafik L, Bonnier P, Martin PM. Outcome of Epstein-Barr virus-associated primary breast cancer. $\mathrm{Mol}$ Clin Oncol. 2015 Mar;3(2):295-8.

3 Prabhu SR, Wilson DF. Evidence of EpsteinBarr virus association with head and neck cancers: a review. J Can Dent Assoc. 2016 Jan; 82:g2.

4 Labrecque LG, Barnes DM, Fentiman IS, Griffin BE. Epstein-Barr virus in epithelial cell

Epstein-Barr Virus Infection and Breast Carcinoma tumors: a breast cancer study. Cancer Res. 1995 Jan;55(1):39-45.

5 Stroup DF, Berlin JA, Morton SC, Olkin I, Williamson GD, Rennie D, et al. Meta-analysis of observational studies in epidemiology: a proposal for reporting. Meta-Analysis of Observational Studies in Epidemiology (MOOSE) group. JAMA. 2000 Apr;283(15): 2008-12.

6 Wells GA, Shea B, O'Connell D, Peterson J, Welch V, Losos M, et al. The Newcastle-Ottawa Scale (NOS) for assessing the quality of non-randomized studies in meta-analysis [Internet] [accessed Feb 2017]. Available from: http://www.ohri.ca/programs/clinical_ epidemiology/oxford.asp.
7 Pai T, Gupta S, Gurav M, Nag S, Shet T, Patil $\mathrm{A}$, et al. Evidence for the association of Epstein-Barr virus in breast cancer in Indian patients using in-situ hybridization technique. Breast J. 2018 Jan;24(1):16-22.

8 El-Naby NE, Hassan Mohamed H, Mohamed Goda A, El Sayed Mohamed A. Epstein-Barr virus infection and breast invasive ductal carcinoma in Egyptian women: a single center experience. J Egypt Natl Canc Inst. 2017 Jun; 29(2):77-82.

9 Fessahaye G, Elhassan AM, Elamin EM, Adam AA, Ghebremedhin A, Ibrahim ME. Association of Epstein-Barr virus and breast cancer in Eritrea. Infect Agent Cancer. 2017 Dec;12(1):62. 
10 Richardson AK, Currie MJ, Robinson BA, Morrin H, Phung Y, Pearson JF, et al. Cytomegalovirus and Epstein-Barr virus in breast cancer. PLoS One. 2015 Feb;10(2):e0118989.

11 Yahia ZA, Adam AA, Elgizouli M, Hussein A, Masri MA, Kamal M, et al. Epstein Barr virus: a prime candidate of breast cancer aetiology in Sudanese patients. Infect Agent Cancer. 2014 Mar;9(1):9.

12 Mohammadizadeh F, Zarean M, Abbasi M. Association of Epstein-Barr virus with invasive breast carcinoma and its impact on wellknown clinicopathologic parameters in Iranian women. Adv Biomed Res. 2014 Jun;3(1): 141.

13 Peng J, Wang T, Zhu H, Guo J, Li K, Yao Q, et al. Multiplex $\mathrm{PCR} /$ mass spectrometry screening of biological carcinogenic agents in human mammary tumors. J Clin Virol. 2014 Oct;61(2):255-9.

14 Khabaz MN. Association of Epstein-Barr virus infection and breast carcinoma. Arch Med Sci. 2013 Aug;9(4):745-51.

15 Morales-Sánchez A, Molina-Muñoz T, Martínez-López JL, Hernández-Sancén $\mathrm{P}$, Mantilla A, Leal YA, et al. No association between Epstein-Barr virus and mouse mammary tumor virus with breast cancer in Mexican women. Sci Rep. 2013 Oct;3(1):2970.

16 Zekri AR, Bahnassy AA, Mohamed WS, ElKassem FA, El-Khalidi SJ, Hafez MM, et al. Epstein-Barr virus and breast cancer: epidemiological and molecular study on Egyptian and Iraqi women. J Egypt Natl Canc Inst. 2012 Sep;24(3):123-31.

17 Kadivar M, Monabati A, Joulaee A, Hosseini N. Epstein-Barr virus and breast cancer: lack of evidence for an association in Iranian women. Pathol Oncol Res. 2011 Sep;17(3): 489-92.

18 Hachana M, Amara K, Ziadi S, Romdhane E Gacem RB, Trimeche M. Investigation of Epstein-Barr virus in breast carcinomas in Tunisia. Pathol Res Pract. 2011 Nov;207(11):695-700.

19 Joshi D, Quadri M, Gangane N, Joshi R, Gangane N. Association of Epstein Barr virus infection (EBV) with breast cancer in rural Indian women. PLoS One. 2009 Dec;4(12): e8180.

20 Fawzy S, Sallam M, Awad NM. Detection of Epstein-Barr virus in breast carcinoma in Egyptian women. Clin Biochem. 2008 May; 41(7-8):486-92.

21 Preciado MV, Chabay PA, De Matteo EN, Gonzalez P, Grinstein S, Actis A, et al. Epstein-Barr virus in breast carcinoma in $\mathrm{Ar}$ gentina. Arch Pathol Lab Med. 2005 Mar; 129(3):377-81.

22 Kalkan A, Ozdarendeli A, Bulut Y, Yekeler H, Cobanoglu B, Doymaz MZ. Investigation of Epstein-Barr virus DNA in formalin-fixed and paraffin-embedded breast cancer tissues. Med Princ Pract. 2005 Jul-Aug;14(4):268-71.

23 Trabelsi A, Rammeh S, Stita W, Mokni M, Mourou A, Korbi S. Detection of EpsteinBarr virus in breast cancers with lymphoid stroma [in French]]. Ann Biol Clin (Paris). 2008 Jan-Feb;66(1):59-62.

24 Glaser SL, Canchola AJ, Keegan TH, Clarke CA, Longacre TA, Gulley ML. Variation in risk and outcomes of Epstein-Barr virus-associated breast cancer by epidemiologic characteristics and virus detection strategies: an exploratory study. Cancer Causes Control. 2017 Apr;28(4):273-87.

25 Arbach H, Viglasky V, Lefeu F, Guinebretière JM, Ramirez V, Bride N, et al. Epstein-Barr virus (EBV) genome and expression in breast cancer tissue: effect of EBV infection of breast cancer cells on resistance to paclitaxel (Taxol). J Virol. 2006 Jan;80(2):845-53.

26 Khan G, Philip PS, Al Ashari M, Houcinat Y, Daoud S. Localization of Epstein-Barr virus to infiltrating lymphocytes in breast carcinomas and not malignant cells. Exp Mol Pathol. 2011 Aug;91(1):466-70.

27 Huo Q, Zhang N, Yang Q. Epstein-Barr virus infection and sporadic breast cancer risk: a meta-analysis. PLoS One. 2012;7(2):e31656.

28 Naushad W, Surriya O, Sadia H. Prevalence of EBV, HPV and MMTV in Pakistani breast cancer patients: a possible etiological role of viruses in breast cancer. Infect Genet Evol. 2017 Oct;54:230-7.

29 Glenn WK, Heng B, Delprado W, Iacopetta B, Whitaker NJ, Lawson JS. Epstein-Barr virus, human papillomavirus and mouse mammary tumour virus as multiple viruses in breast cancer. PLoS One. 2012;7(11):e48788. 